\title{
How Reliable are Farmers' Perceptions about Climate Change? A Case Study in the Upper East Region of Ghana
}

\author{
Abdul-Razak Zakaria ${ }^{1}$, Kenichi Matsui $^{2}$
}

\author{
${ }^{1}$ Graduate School of Life and Environmental Sciences, The University of Tsukuba, Japan \\ Email: nurazak830@gmail.com \\ ${ }^{2}$ Faculty of Life and Environmental Sciences, The University of Tsukuba \\ Email: kenichim@envr.tsukuba.ac.jp
}

\begin{abstract}
The 2014 IPCC report reiterated the importance of local farmers' perceptions about climate change. A growing number of scientists supports that farmers' in-depth understanding of climate change hazards and their active participation in mitigation actions are key to improving adaptation. This paper attempts to analyze smallholder rice farmers' perceptions and knowledge about climate change hazards in the Upper East Region of Ghana mainly by looking at the national climatic data and the results of the questionnaire survey we conducted. The climatic data were further analyzed through the Mann-Kendall trend test to find relations between actual rainfall and temperature changes with farmers' observations. Our analysis on perceptions shows that more than $60 \%$ of the respondents experienced climate hazards in the forms of increasing temperature, decreasing rainfall and changing planting time. This result is also supported by the Mann-Kendall trend test. The change in planting time is attributable to the increasing coefficient of variation of the annual rainfall from 16.5\% (1996-2005) to $28.1 \%$ (2006-2015). It is also due to substantial rainfall deviations within the Region in May, from 1,000 $\mathrm{mm}$ in the decade between 1996 and 2005 to $500 \mathrm{~mm}$ in the following decade (2006-2015). We argue that farmers' observations are largely reliable particularly in observing changes in rainfall patterns. Their observations can also supplement insufficient local meteorological records to better understand local climate change conditions in Western Africa.
\end{abstract}

Keywords - Climate change, farmer's perceptions, food security, rainfall and temperature patterns.

\section{INTRODUCTION}

The African continent is known to be particularly vulnerable to climate change (Boko et al., 2007). Most parts of Africa have experienced rising near surface temperatures by $0.5^{\circ} \mathrm{C}$ or more in the past 50 to 100 years. It is projected that further changes in precipitation, temperature and $\mathrm{CO}_{2}$ level in the atmosphere will cause serious damage to terrestrial ecosystems and agriculture (Niang et al., 2014).

In Ghana, compelling evidence shows temperature increase and rainfall decrease (Antwi-Agyei 2012; Dietz et al., 2004; Issahaku et al., 2016; Nkrumah et al., 2014, Stanturf et al., 2011). It is also projected that this trend will continue (Amuakwa-Mensah, 2014, Dietz et al., 2004). Many researchers have discussed climate change impacts on agriculture in Ghana and other Sub-Saharan African countries (Makate et al., 2017; Mertz et al., 2008; OECDFAO, 2016) and noted discrepancy and deficiency in observed rainfall data (UNECA, 2014; Niang et al., 2014).
As a result, a number of researchers have examined farmers' perceptions about climate change impacts to better understand vulnerability, coping capacity and adaptation (Allahyari et al., 2016; Deressa et al., 2010; Fosu-Mensah et al., 2012; Ghosh et al., 2015; Salick and Byg, 2007). The 2014 IPCC report demonstrates the increasing recognition and integration of local farmers' perceptions/awareness about climate change among scientists (IPCC, 2014). Growing evidence supports that farmers' in-depth understanding about climate change hazards is key to improving adaptation (Niang et al., 2014).

Here the fundamental and debatable question arise as to the extent to which farmers' perceptions about climate change are reliable to understand local climatic conditions. To deal with this concern, we attempt to validate farmers' perceptions about climate change by comparing with the actual meteorological data in the same study area for two decades (1996 to 2015). 


\section{RESEARCH METHODOLOGY}

\subsection{Study area}

This research was conducted in five districts of the Upper East Region, one of three northern regions of Ghana. The region is located at $10.7082^{\circ} \mathrm{N}, 0.9821^{\circ} \mathrm{W}$ and covers an area of $8,842 \mathrm{~km} 2$. The population density is 103 persons $/ \mathrm{km} 2$. Agriculture is the dominant economic activity here. It employs $80 \%$ of the population. It is also the second poorest region in Ghana. Its climate is characterized by two distinct seasons: the wet season from May to October, and the dry season from November to April. Mean annual rainfall in the region ranges from 950 $\mathrm{mm}$ to $1,100 \mathrm{~mm}$ (Ghana Statistical Service, 2014).

The Upper East Region is one of the major rice producing regions in Ghana. Most recent statistics shows that it accounted for about $21 \%$ of rice output in the nation (MOFA, 2016). Non-irrigated rice farming is practiced in all thirteen districts in the region, while irrigated rice farming is practiced in only three districts near Tono and Vea dams. Average farm size per household is 1.3 hectares with a low average yield of $1.8 \mathrm{t} / \mathrm{ha}$ (compared with the national average of $2 \mathrm{t} / \mathrm{ha}$ ). Hoe, cutlass and in some cases bullock ploughs and sickle are mainly used for cultivation.

\subsection{Sampling}

A preliminary survey was carried out to understand the feasibility and significance of the survey for the local participants. Considering the significance of rice production, we selected five out of 13 districts: Bawku West, Binduri, Garu-Tempane, Pusiga and Bawku East. In these districts, we applied stratified random sampling to select sample communities. Using simple random sampling, we selected three representative farming communities in each district and interviewed ten farmers in each community (Table 1). In total, 150 farmers fully participated in our survey. The selected districts have similar characteristics in terms of the climate, soil type, farming system, culture, language and cultivated crops (Ghana Statistical Service, 2014). Due to its similar characteristics, it is mainly known as "Bawku zone."

\begin{tabular}{llll}
\multicolumn{2}{c}{ Table.1: Summary of sampled districts and communities } \\
\hline Districts & District & Sampled & Sample \\
& population & communities & size \\
\hline Bawku & 94,034 & Boya-natinga & 10 \\
West & & Gumbo-natinga & 10 \\
& & Gozesi & 10 \\
Binduri & \multirow{2}{*}{61,576} & Azum-sapeliga & 10 \\
& & Nayoko & 10 \\
& & Yalugu & 10 \\
Garu- & \multirow{2}{*}{130,003} & Azimbasi & 10 \\
Tempane & & Baring & 10
\end{tabular}

\begin{tabular}{llll}
\hline \multirow{3}{*}{ Pusiga } & \multirow{3}{*}{57,677} & Yiziidug & 10 \\
& & Dabia & 10 \\
& & Suande & 10 \\
Bawku East & \multirow{2}{*}{98,538} & Zong-natinga & 10 \\
& & Gentiga & 10 \\
& & Kuka yakin & 10 \\
Total & 441,828 & Tampizua & 10 \\
& & 15 & 150
\end{tabular}

(Ghana Statistical Service, 2014)

\subsection{Data collection and analysis}

In the survey, we first attempted to identify sociodemographic characteristics of the respondents partly to understand whether these characteristics influenced their perceptions. We then asked the respondents to describe their observations about long-term (20 years) temperature, rainfall patterns and changes. They were also asked to note if they had made any changes in planting seasons in response to climate change. As most respondents had limited reading and writing skills in English, the questionnaire was interviewer-administered. Also, to overcome language barrier, we translated the questions into the local language. As a result, we had $100 \%$ response rate. Survey responses were coded and analyzed in the statistical package for social sciences (SPSS version 20) worksheet. To ascertain climate change patterns in the selected districts, we gathered annual rainfall and temperature data from 1996 to 2015. These data are available at the meteorological department of the Manga Savannah Research Institute (SARI). We used XLSTAT 2017 software to conduct the analysis. We also applied the coefficient of variation $(\mathrm{CV})$ technique to assess the annual and seasonal rainfall variations.

Several studies have employed the Mann-Kendall trend (Mann 1945; Kendall 1975) and the Sen's estimator (Sen 1968) to analyze rainfall and temperature data (Kiros et al., 2016; Gajbhiye et al., 2016; Kabo-Bah et al., 2016; Merabtene et al., 2016; Partal et al., 2011; Rahmat et al., 2006; Yadav et al., 2014). It is a non-parametric trend test for time series data. It enables us to determine whether there is a trend in the time series data or not. Null hypothesis $\left(\mathrm{H}_{0}\right)$ is that there is no trend in the data series. The alternate hypothesis $\left(\mathrm{H}_{\mathrm{a}}\right)$ is that there is a trend in the data series. The null hypothesis $\left(\mathrm{H}_{\mathrm{o}}\right)$ is rejected if the $\mathrm{p}$ value is lower than the significance level. However, when the p-value is higher than the significance level, then we accept the null hypothesis $\left(\mathrm{H}_{\mathrm{o}}\right)$. The result of the MannKendall test, which shows the statistical significance of the trend in the data set, is usually complemented with the Sen's slope estimator, which denotes the magnitude of the 
trend. The mathematical representation of the MannKendall trend test is as follows:

The nth time series values denoted as: $\mathrm{X} 1, \mathrm{X} 2, \mathrm{X} 3 \ldots$, $\mathrm{Xn}$ are replaced in equation (1) below by their relative ranks, R1, R2, R3..., Rn.

$S=\sum_{i=1}^{n}\left\{\sum_{j=i+1}^{n} \operatorname{sgn}\left(R_{i}-R_{j}\right)\right\}$

where,

$$
\operatorname{sgn}(x)=1 \text { for } x>1
$$

$\operatorname{sgn}(x)=0$ for $x=0$

$\operatorname{sgn}(x)=-1$ for $x<0$

Should null hypothesis $\left(\mathrm{H}_{\mathrm{o})}\right.$ is true, then $\mathrm{S}$ is approximately normally distributed with: $\mu=0$

$\delta=n \frac{(n-1)(2 n+5)}{18}$

For data sample (n) larger than 10, the standard test statistic $\mathrm{Z}$ is computed as the Mann-Kendall test statistic as follows:

$$
Z= \begin{cases}\frac{S-1}{\sqrt{\operatorname{var}(S)}} & \text { if } S>0 \\ 0 & \text { if } S=0 \\ \frac{S+1}{\sqrt{\operatorname{var}(S)}} & \text { if } S<0\end{cases}
$$

The presence of a statistically significant trend is evaluated by using the $Z$ value. Positive values of $Z$ indicate an increasing trend, while negative values show decreasing trends. To test for either an increasing or decreasing monotonic (increasing or decreasing) trend at $\alpha$ level of significance, $\mathrm{H}_{\mathrm{o}}$ should be rejected if $|z|>Z_{1-\alpha / 2}$, where $Z_{1-\alpha / 2}$ is obtained from the standard cumulative distribution tables.

The Sen's estimator is determined using the equation (3):

$\beta=\operatorname{Median} \frac{x_{j}-x_{i}}{j-i}$ for all $i \leq j$

where; $\beta$ is the robust estimate of the trend magnitude. A positive value of $\beta$ indicates an "upward trend," and a negative value indicates a "downward trend" (Yadav et al., 2014; Rahmat et al., 2015).

The coefficient of variation (CV) explains the deviation in a data series from its central tendencies. The coefficient of variability is found by expressing the standard deviation of a data set as a percentage of its mean value (Bari et al.,
2017). Precipitation is the most important parameter that shapes hydrology, water quality and vegetation. If the CV value is high, it depicts a larger spatial variation in the data set (Gajbhiye et al., 2016).

\section{RESULTS AND DISCUSSION}

3.1 Socio-demographic characteristics of respondents Regarding the socio-demographic characteristics of the respondents, we found that $61 \%$ belonged to an age bracket of 30-49 years old. Male respondents consisted of $64 \%$. However, this does not mean that males dominate rice farming in our study area. Actually, we observed that women were predominant workers in rice farming. In terms of education levels, $81 \%$ had no formal education. This constituted $89 \%$ of the total female respondents and $76 \%$ of the total male respondents. The literacy rate of the female respondents was below the estimated 2018 national literacy level of $76 \%$ (Countrymeters, 2018). Despite this social setback, almost $70 \%$ of the respondents had more than 11 years of experience in rice farming (Table 2). Hence their perceptions about long-term climate variability can be overall compatible to the recorded climate data we use.

Table.2: Socio-demographic characteristics of respondents

\begin{tabular}{lll}
\hline $\begin{array}{l}\text { Social } \\
\text { characteristics }\end{array}$ & Category & Frequency (\%) \\
\hline Age & $20-29$ & $10(7 \%)$ \\
& $30-39$ & $33(22 \%)$ \\
& $40-49$ & $59(39 \%)$ \\
& $50-59$ & $28(19 \%)$ \\
& $60 \&$ above & $20(13 \%)$ \\
Gender & Female & $54(36 \%)$ \\
Education & Male & $96(64 \%)$ \\
& Junior high & $15(10 \%)$ \\
& Senior high & $4(3 \%)$ \\
& Tertiary & $7(5 \%)$ \\
& Non-formal & $3(2 \%)$ \\
Years & No education & $121(80 \%)$ \\
experience in rice & $11-20$ & $47(31 \%)$ \\
farming & of & $59(39 \%)$ \\
& $21-30$ & $30(20 \%)$ \\
& $31-40$ & $9(6 \%)$ \\
& $41-50$ & $4(3 \%)$ \\
& $51-60+$ & $1(1 \%)$ \\
& & 150 \\
\hline
\end{tabular}


3.2 Respondents' perceptions about climate change

To understand farmers' perceptions about climate change, we attempted to identify respondents' perceptions about changes in temperature, rainfall pattern, planting time and drought frequency. If they observed changes, we then attempted to find out what impacts, if any, they experienced. The respondents stated that temperature $(62 \%)$ and drought frequency had increased (65\%), whereas rainfall had decreased $(84 \%)$. In response, they had changed planting time $(82 \%)$. In all five districts of the Bawku zone, $98 \%$ of the respondents experienced declining rice yields on their farms (Table 3). Overall, nearly all respondents $(98 \%)$ believed that climate change and weather-related hazards had reduced rice yields.

Table.3: Gender and farmers' perceptions crosstabulation

\begin{tabular}{|c|c|c|c|}
\hline $\begin{array}{l}\text { Gender and farmers' } \\
\text { perceptions }\end{array}$ & Female & Male & Total \\
\hline \multirow[t]{4}{*}{ Increasing temperature } & 25 & 32 & 57 \\
\hline & $46 \%$ & $33 \%$ & $38 \%$ \\
\hline & 29 & 64 & 93 \\
\hline & $54 \%$ & $67 \%$ & $62 \%$ \\
\hline \multirow[t]{4}{*}{ Decreasing rainfall } & 9 & 15 & 24 \\
\hline & $17 \%$ & $16 \%$ & $16 \%$ \\
\hline & 45 & 81 & 126 \\
\hline & $83 \%$ & $84 \%$ & $84 \%$ \\
\hline \multirow[t]{4}{*}{ Changing planting time } & 7 & 20 & 27 \\
\hline & $13 \%$ & $21 \%$ & $18 \%$ \\
\hline & 47 & 76 & 123 \\
\hline & $87 \%$ & $79 \%$ & $82 \%$ \\
\hline \multirow[t]{4}{*}{ Increasing drought } & 25 & 27 & 52 \\
\hline & $46 \%$ & $28 \%$ & $35 \%$ \\
\hline & 29 & 69 & 98 \\
\hline & $54 \%$ & $72 \%$ & $65 \%$ \\
\hline \multirow[t]{4}{*}{ Reduced crop yield } & 1 & 2 & 3 \\
\hline & $2 \%$ & $2 \%$ & $2 \%$ \\
\hline & 53 & 94 & 147 \\
\hline & $98 \%$ & $98 \%$ & $98 \%$ \\
\hline \multirow[t]{2}{*}{ Total } & 54 & 96 & 150 \\
\hline & $100 \%$ & $100 \%$ & $100 \%$ \\
\hline
\end{tabular}

During our field observation, we found different gender roles in producing rice in the study area. We attempted to see if gender difference affected local climate change perceptions. We conducted a chi-squared analysis and found a significant gender difference regarding drought events $(\chi 2=5.038$, df $=5$ and $\mathrm{p}=0.025)$ (Table 4). Whereas $72 \%$ of the males perceived increasing drought events, $54 \%$ of the females did so (Table 3 ). Although we cannot identify a definite reason to explain this gender disparity, we observed that the male respondents visited their farms more often than their female counterparts largely because the women had to attend to household chores and childcare.

Table.4: Socio-demographics and farmers' perceptions

\begin{tabular}{lccccc}
\hline & $\begin{array}{l}\text { Increasi } \\
\text { ng } \\
\text { temp. }\end{array}$ & $\begin{array}{l}\text { Decreasi } \\
\text { ng } \\
\text { rainfall }\end{array}$ & $\begin{array}{l}\text { Changi } \\
\text { ng } \\
\text { plantin } \\
\text { g time }\end{array}$ & $\begin{array}{l}\text { Increasi } \\
\text { ng } \\
\text { drought }\end{array}$ & $\begin{array}{l}\text { Reduc } \\
\text { ed } \\
\text { crop } \\
\text { yield }\end{array}$ \\
\hline Age & 0.17 & 4.69 & 2.78 & 4.35 & 5.77 \\
& $(0.99)$ & $(0.32)$ & $(0.59)$ & $(0.36)$ & $(0.22)$ \\
Gender & 2.46 & 0.03 & 1.45 & 5.04 & 0.01 \\
& $(0.12)$ & $(0.86)$ & $(0.23)$ & $(0.03 *)$ & $(0.92)$ \\
Educatio & 0.71 & 2.34 & 12.34 & 0.33 & 0.73 \\
n & $(0.95)$ & $(0.67)$ & $\left(0.02^{*}\right)$ & $(0.98)$ & $(0.95)$ \\
Experien & 2.916 & 10.044 & 5.665 & 5.212 & 2.982 \\
ce & $(0.71)$ & $(0.74)$ & $(0.34)$ & $(0.39)$ & $(0.70)$ \\
\hline
\end{tabular}

Note: Numbers in parentheses denote the p-value.

3.3 Meteorological data analysis

We examined the extent to which the above findings correspond with the meteorologically recorded rainfall and temperature data in the five districts. The lowest and highest annual rainfall were $671 \mathrm{~mm}$ and 1,562 $\mathrm{mm}$ between 1996 and 2015. The p-value of 0.048 showed a decreasing trend in annual rainfall in the area (Table 5). The Sen's slope value of -14.572 suggested that rainfall decreased at a rate of about $15 \%$ annually in the past twenty years.

Similarly, the highest and lowest temperature were $37.2^{\circ} \mathrm{C}$ and $20.5^{\circ} \mathrm{C}$ between 1996 and 2015. The p-value for the maximum temperature of 0.003 means that there existed a trend in the data set. However, the p-value for the minimum temperature of 0.795 shows no trend in the minimum temperature data set (Table 6). The Sen's slope indicates that the maximum temperature increased by 0.055. It also indicates that the minimum temperature decreased by 0.011 . The decrease in minimum temperature, however, was not significant.

Considering the reliability of farmers' perceptions about increasing temperature and drought events, decreasing rainfall and changing planting time, we conducted the Mann-Kendall trend test. The result showed positive relations. This implies that the respondents' perceptions, especially more experienced ones, sufficiently demonstrated a reliable understanding and knowledge about changes in multiple climate conditions in the area. These results positively correspond with previous related studies (Kabo-Bah et al., 2016; Ofori-Sarpong, 2001; Zampaligré et al., 2014; Gbetibouo, 2009; Fosu-Mensah et al., 2012). 
To understand the validity of farmers' responses to climate change by changing planting time, we calculated and examined two decades coefficient of variation in annual rainfalls in two ten-year periods: 1996-2005 and 2006-2015. The results were $16.5 \%$ and $28.1 \%$, respectively. This result means that the average annual rainfall in the area varied substantially between 2006 and 2015 by $28 \%$. Also, a graphical plot of the monthly rainfall data in the study area between 1996-2005 and 2006-2015 revealed a substantial shift in the timing and amount of rainfall. In the first decade, maximum attainable rainfall was $1,000 \mathrm{~mm}$ whereas the second decade experienced a maximum rainfall of $500 \mathrm{~mm}$ in May (Figures 2 and 3). Generally, however, the growing season in this area starts from May and ends in October (Ghana Statistical Service, 2014).

Table.5: Trend test for average annual rainfall $(\mathrm{mm})$ Mann-Kendall trend test / Two-tailed test (Average Annual rainfall (mm)

\begin{tabular}{ll}
\hline Kendall's tau & -0.326 \\
$\mathrm{~S}$ & -62.000 \\
Var(S) & 950.000 \\
p-value (Two-tailed) & 0.048 \\
Alpha & 0.05 \\
\hline
\end{tabular}

Table.6: Trend test for average annual maximum and minimum temperatures $\left({ }^{\circ} \mathrm{C}\right)$

\begin{tabular}{llll}
\hline $\begin{array}{l}\text { Mann-Kendall } \\
\text { test/Two-tailed } \\
\text { (Maximum temperature) }\end{array}$ & $\begin{array}{r}\text { trend } \\
\text { test }\end{array}$ & $\begin{array}{l}\text { Mann-Kendall } \\
\text { test/Two-tailed } \\
\text { (Minimum temperature) }\end{array}$ & $\begin{array}{r}\text { trend } \\
\text { test }\end{array}$ \\
\hline Kendall's tau & 0.495 & Kendall's tau & 0.047 \\
$\mathrm{~S}$ & 94 & $\mathrm{~S}$ & -9 \\
Var (S) & 950 & Var (S) & 949 \\
p-value & (Two- & 0.003 & p-value \\
tailed) & & tailed) & 0.795 \\
Alpha & 0.05 & Alpha & 0.05 \\
\hline
\end{tabular}

\section{CONCLUSION}

This paper has demonstrated that smallholder rice farmers in the Upper East Region of Ghana have carefully observed multiple climate change events and responded to these challenges. More than $60 \%$ of the respondents perceived increasing temperature and drought frequency as well as decreasing rainfalls $(84 \%)$. Nearly all respondents (98\%) experienced crop yield reduction due to climaterelated hazards. In response, $82 \%$ of our respondents changed their planting time.

Their climate observation and remedial actions substantially corresponded with the meteorologically recorded climate data. From 2006 to 2015, the trend of decreasing rainfall in the study area became severe. Rainfall decreased at the rate of about $15 \%$ annually. The detected shift in the monthly rainfall decreased from 1,000 $\mathrm{mm}$ in the 1996-2005 period to $500 \mathrm{~mm}$ in the 2006-2015 period.

Farmers' knowledge about changing climate conditions is based on their careful daily observation. Local farmers, especially experienced ones, can help scientists and policymakers better understand increasingly localized climate events and hazards. Their knowledge can better inform climate-related decision making as well as food security policies in Ghana and Sub-Saharan Africa at large. In turn, policymakers' better understanding about farmers' capacities and needs will make agricultural policies more climate adaptive in the future.

\section{ACKNOWLEDGEMENT}

We are very grateful to the Manga Savannah Agricultural Research Institute and 150 farmers who cooperated with us and provided information for this research.

\section{REFERENCES}

[1] Allahyari, M. S., Ghavami, S., and Masuleh, Z. D. (2016). Understanding Farmers' Perceptions and Adaptations to Precipitation and Temperature Variability: Climate, 4 (58), 1-16. https://doi.org/10.3390/cli4040058.

[2] Antwi-Agyei, P. (2012). Vulnerability and adaptation of Ghana's food production systems and rural livelihoods to climate variability. Ph.D. diss., University of Leeds, School of Earth and Environment. http://etheses.whiterose.ac.uk/5044/. Viewed on June 25, 2018.

[3] Antwi-Agyei, P., Stringer, L. C., and Dougill, A. J. (2014). Livelihood adaptations to climate variability: Insights from farming households in Ghana. Regional Environmental Change, 14 (4), 1615-1626. https://doi.org/10.1007/s10113014-0597-9.

[4] Boko, M., Niang I., Nyong A., Vogel C., Githeko A., Medany M., Osman-Elasha B., Tabo R., and Yanda P. (2007). Africa. Climate Change 2007: Impacts, Adaptation and Vulnerability. Contribution of Working Group II to the Fourth Assessment Report of the Intergovernmental Panel on Climate Change. Eds: Parry, M. L., Canziani, O.F., Palutikof, J. P., van der Linden, P. J. and Hanson, C. E. Cambridge University Press, Cambridge UK, pp. 433-467.

[5] Connolly-Boutin, L., and Smit, B. (2016). Climate change, food security, and livelihoods in sub-Saharan Africa. Regional Environmental Change, 16 (2), 385-399. https://link.springer.com/article/10.1007/s10113-015-0761-x

[6] Countrymeters. (2018). Ghana Population. Countrymeters.info/en/Ghana. http://countrymeters.info/en/Ghana\#literacy. Viewed on March 5, 2018.

[7] Fosu-Mensah, B. Y., Vlek, P. L. G., and Mac Carthy, D. S. (2012). Farmers' perception and adaptation to climate change: a case study of Sekyedumase district in Ghana. Environment, Development and Sustainability, 14 (4), 495505. https://doi.org/10.1007/s10668-012-9339-7. 
[8] Gajbhiye, S., Meshram, C., Mirabbasi, R., and Sharma, S. K. (2016). Trend analysis of rainfall time series for Sindh river basin in India. Theoretical and Applied Climatology, 125 (34), 593-608. https://doi.org/10.1007/s00704-0151529-4.

[9] Gbetibouo, G. A. (2009). Understanding farmers' perceptions and adaptations to climate change and variability: The case of the Limpopo Basin, South Africa (Vol. 849). Intl Food Policy Res Inst.

[10] Ghana Statistical Service-Bawku Municipality. (2014). District Analytical Report-Bawku Municipality. Population and Housing Census, 1-70. Retrieved from http://www.statsghana.gov.gh/docfiles/2010_District_Repor t/Upper East/BawkuMunicipality.pdf. Viewed on January $14,2020$.

[11] Ghana Statistical Service-Pusiga. (2014). District Analytical Report-Pusiga District. Population and Housing Census, 171. Retrieved from http://www.statsghana.gov.gh/docfiles/2010_District_Repor t/Upper East/Pusiga.pdf. Viewed on January 14, 2020.

[12] Ghana Statistical Service- Bawku West. (2014). 2010 Population and Housing Census Analytical Report: Bawku West District. Ghana Statistical Service, 1-75. Retrieved from https://new-ndpcstatic1.s3.amazonaws.com/CACHES/PUBLICATIONS/201 6/06/06/Bawku+West+2010PHC.pdf. Viewed on January 14, 2020.

[13] Ghana Statistical Service-Garu-Tempane. (2014). District Analytical Report-Garu-Tempane District. Population and Housing Census, 1-79. Retrieved from http://www2.statsghana.gov.gh/docfiles/2010_District_Repo rt/Upper\%20East/GARU\%20TEMPANE.pdf. Viewed on January 14, 2020.

[14] Ghana Statistical Service-Binduri, (2014). District Analytical Report - Binduri District. Population and Housing Census, 1-70. Retrieved from http://www2.statsghana.gov.gh/docfiles/2010_District_Repo rt/Upper\%20East/BINDURI.pdf. Viewed on January 14, 2020.

[15] Ghosh, B. C., Osmani, M. A. G., and Hossain, M. E. (2015). Perception of and adaption capacities to climate change adaption strategies by the rice farmers: A case of Rajshahi District in Bangladesh. Journal of Economics and Sustainable Development. 6 (2),136-145.

[16] Issahaku, A., Campion, B. B., and Edziyie, R. (2016). Rainfall and temperature changes and variability in the Upper East Region of Ghana. Earth and Space Science. 3, 284-294. https://doi.org/10.1002/2016EA000161

[17] Kabo-Bah, A., Diji, C., Nokoe, K., Mulugetta, Y., ObengOfori, D., and Akpoti, K. (2016). Multiyear Rainfall and Temperature Trends in the Volta River Basin and their Potential Impact on Hydropower Generation in Ghana. Climate, 4 (49), 1-17. https://doi.org/10.3390/cli4040049.

[18] Karanja, J. M. and Zakaria, A-R. (2018). Africa and Climate Change Refugees Quandary: Kenya Perspectives. In: Akanle O., and Adesina J. (eds) The Development of Africa. Social Indicators Research Series, vol 71. Springer, Cham. pp. 255267.

[19] Kiros, G., Shetty, A., and Nandagiri, L. (2016). Analysis of variability and trends in rainfall over northern Ethiopia. Arabian Journal of Geosciences, 9 (451), 1-12. https://doi.org/10.1007/s12517-016-2471-1.

[20] Merabtene, T., Siddique, M., and Shanableh, A. (2016). Assessment of Seasonal and Annual Rainfall Trends and Variability in Sharjah City, UAE. Advances in Meteorology, 2016. https://doi.org/10.1155/2016/6206238.
[21] Mertz, O., Halsnæs, K., Olesen, J. E., and Rasmussen, K. (2009). Adaptation to Climate Change in Developing Countries. Environmental Management, 43 (5), 743-752. https://doi.org/10.1007/s00267-008-9259-3.

[22] Niang, I., Ruppel, O. C., Abdrabo, M. A. Essel A., Lennard C., Padgham J., and Urquhart P.., (2014). Africa. Chapter 22. In: Climate Change 2014: Impacts, Adaptation, and Vulnerability. Part B: Regional Aspects. Contribution of Working Group II to the Fifth Assessment Report of the intergovernmental Panel on Climate Change, edited by Barros, V.R., et al. (eds.)]. Cambridge, UK, and New York, USA: Cambridge University Press, pp. 1199-1265.

[23] Makate, C., Makate, M., and Mango, N. (2017). Smallholder Farmers' Perceptions on Climate Change and the Use of Sustainable Agricultural Practices in the Chinyania Triangle, South Africa. Social Sciences. 6 (30), 1-15. https://doi.org/10.3390/socsci6010030.

[24] OCED and FAO (2016). OECD-FAO Agricultural Outlook 2016-2025. Special Focus. Sub-Sahara Africa. http://www.fao.org/3/a-i5778e.pdf. Viewed on August 7, 2018.

[25] Partal, T., and Kahya, E. (2005). Trend analysis in Turkish precipitation data. Hydrol. Process. 20, 2011-2026. https://doi.org/10.1002/hyp.5993.

[26] Rahmat, S. N., Jayasuriya, N., and Bhuiyan, M. A. (2006). Precipitation trends in Victoria, Australia. Journal of Water and Climate Change, 6 (2), 278-287. https://doi.org/10.2166/wcc.2014.007.

[27] Salick, J., and Anja, B., (2007). Indigenous People and Climate Change. Missouri Botanical Garden. 1-32.

[28] Stanturf, J., Warren, M., Charnley, S., Polasky, C., Goodrick, S., Armah, F., and Nyako, Y. (2011). Ghana climate change vulnerability and adaptation assessment. Washington, DC: USAID. http://www.encapafrica.org/documents/biofor/Climate\%20C hange\%20Assessment_Ghana_\%20FINAL.pdf. Viewed on April 6, 2018.

[29] United Nations Economic Commission for Africa (UNECA) Annual Report. (2014). Thirty-third meeting of the Committee of Experts. https://www.uneca.org/sites/default/files/uploadeddocuments/CoM/com2014/annual_report_2014_eng.pdf. Viewed on June 8, 2018.

[30] Yadav, R., Tripathi, S. K., Pranuthi, G., and Dubey, S. K. (2014). Trend analysis by Mann-Kendall test for precipitation and temperature for thirteen districts of Uttarakhand. Journal of Agrometeorology, 16 (2), 164-171. http://agrimetassociation.org/Images/Paper/16/4/1/229.pdf

[31] Zampaligré, N., Dossa, L. H., and Schlecht, E. (2014). Climate change and variability: Perception and adaptation strategies of pastoralists and agro-pastoralists across different zones of Burkina Faso. Regional Environmental Change, 14 (2), 769-783. https://doi.org/10.1007/s10113013-0532-5 